\title{
PENGARUH FORTIFIKASI BESI DAN ZINC TERHADAP TOTAL BAKTERI ASAM LAKTAT, pH, DAN ORGANOLEPTIK YOGHURT SUSU KAMBING SINBIOTIK
}

\author{
Firdha Ayu Trianie, Ninik Rustanti*) \\ Program Studi Ilmu Gizi Fakultas Kedokteran Universitas Diponegoro \\ J1.Dr.Sutomo No.18, Semarang, Telp (024) 8453708, Email : gizifk@ undip.ac.id
}

\begin{abstract}
Background :Prevalence of anemia is increased annually. One of the prevention strategies in anemia is milk fortification. Milk is a good medium for fortification because of its high bioavailability property and has high consumption rate among society. Goat milk has higher nutritive value than cow milk, but it is also produces volatile fatty acid which creates unpleasant odor. Yoghurt with additions of Lactobacillus bulgaricus andStreptococcus thermophilusis able to minimize unpleasant odor. Zinc fortification is useful to prevents fat oxidation caused by Iron which can leads to rancidity.

Method: This was an experiment study with a one-factor complete randomized design of fortification of FeSO4 and $\mathrm{ZnCl2}$. Analysis of $\mathrm{pH}$ was conducted using $\mathrm{pH}$ meter. Total plate count method was used to calculate total Lactic Acid Bacteria along with organoleptic test. All data's collected from total lactic acid bacteria and $\mathrm{pH}$ were analyzed using One Way ANOVA followed by Post Hoc test, while the results of organoleptic test were analyzed using Friedman test followed by Wilcoxon test.

Result:Goat milk's yogurt with fortification of FeSO4 (4.73) and FeSO4 + ZnCl2 (4.75) had higher pH than control group. Total LAB on FeSO4 + ZnCl2 fortification had the lowest amount as much as 9.55x107. Fortification with $\mathrm{FeSO} 4+\mathrm{ZnCl} 2$ was also able to reduce aroma value (2.68), texture (3.28), color (3.28), and taste (2.56).

Conclusion:Fortification with $\mathrm{FeSO}_{4}$ and $\mathrm{FeSO}_{4}+\mathrm{ZnCl}_{2}$ were able to decreased total LAB significantly and increased $\mathrm{pH}$ value. Fortification with $\mathrm{FeSO}_{4}$ and $\mathrm{FeSO}_{4}$ were also able to decreased aroma value and texture significantly, although the decline of color and taste value were not statistically significant.
\end{abstract}

Keyword : fortification; yoghurt; goatmilk; anemia; synbiotic

\begin{abstract}
ABSTRAK
Latar belakang :Prevalensi anemia terus meningkat setiap tahunnya. Salah satu pencegahan anemia defisiensi besi yaitu dengan fortifikasi pada susu. Susu menjadi media fortifikasi besi yang tepat karena memiliki bioavaibilitas tinggi dan banyak dikonsumsi masyarakat. Susu kambing memiliki nilai gizilebih tinggi dibandingkan susu sapi, namun mempunyai asam lemak volatil yang membuat bau khas kurang sedap. Bau kurang sedap diminimalisir dengan pengolahan menjadi yoghurt menggunakan Lactobacillus bulgaricus dan Streptococcus thermophilus. Fortifikasi Zn bermanfaat dalam melindungi oksidasi lemak oleh Fe sehingga mengurangi ketengikan pada produk. Metode : Merupakan penelitian eksperimen dengan rancangan acak lengkap satu faktor yaitu fortifikasi $\mathrm{FeSO}_{4}$ dan $\mathrm{ZnCl}_{2}$. Analisis pH menggunakan pHmeter, Total BAL menggunakan metode TPC, serta uji organoleptik. Analisis total bakteri asam laktat dan pH menggunakan One Way Anova dilanjutkan Post Hoc dengan Post uji sedangkan aorganoleptik diuji menggunakan Friedman dilanjutkan uji Wilcoxon.

Hasil : pH pada fortifikasi $\mathrm{FeSO}_{4}(4,73)$ dan $\mathrm{FeSO}_{4}+\mathrm{ZnCl}_{2}(4,75)$ yoghurt susu kambing lebih tinggi dibanding dengan kelompok kontrol (4,65). Total bakteri asam laktat dengan fortifikasi $\mathrm{FeSO}_{4}+\mathrm{ZnCl}_{2} \mathrm{memiliki}_{\text {nilai }}$ terendah yaitu $\left(9,55 \times 10^{7}\right)$.Fortifikasi $\mathrm{FeSO}_{4}+\mathrm{ZnCl}_{2}$ menurunkan nilai aroma (2,68), tekstur (3.28) warna (3.52) dan rasa (2.56).

Simpulan : Fortifikasi $\mathrm{FeSO}_{4}$ dan $\mathrm{FeSO}_{4}+\mathrm{ZnCl}_{2}$ menurunkan total bakteri asam laktat secara nyata dan meningkatkan nilai pH.Fortifikasi $\mathrm{FeSO}_{4}$ dan $\mathrm{FeSO}_{4}+\mathrm{ZnCl}_{2}$ menurunkan nilai aroma, tekstur (secara nyata) warna, dan rasa ( secara tidak nyata).
\end{abstract}

Kata Kunci : fortifikasi; yoghurt; susu kambing; anemia; sinbiotik

\section{PENDAHULUAN}

Prevalensi anemia terus meningkat setiap tahunnya, dari 93 negara terdapat $76 \%$ kejadian anemia terjadi pada anak anak. ${ }^{1}$ Salah satu upaya untuk pencegahan anemia defisiensi besi adalah dengan fortifikasi. Fortifikasi merupakan penambahan zat gizi ke dalam produk pangan yang diproduksi sebagai salah satu cara untuk mengatasi masalah defisiensi besi. Besi merupakan mineral yang dibutuhkan tubuh untuk proses oksidasi reduksi serta berperan sebagai transporter oksigen ke seluruh tubuh untuk berbagai proses fisiologis tubuh. Selain besi, Zn juga merupakan mineral yang berperan penting menjaga imunitas tubuh. ${ }^{14}$ Garam besi yang direkomendasikan WHO untuk fortifikasi adalah $\mathrm{FeSO}_{4}$ karena mempunyai sifat yang lebih baik dibandingkan dengan garam

\footnotetext{
${ }^{*}$ Penulis Penanggungjawab
} 
besi lain, bersifat tidak mudah menggumpal dan stabil pada suhu kamar. ${ }^{13}$ Fortifikasi $\mathrm{Zn}$ juga bermanfaat untuk melindungi oksidasi lemak oleh besi sehingga dapat mengurangi ketengikan produk yang dihasilkan. ${ }^{14}$ Fortifikan $\mathrm{Zn}$ yang digunakan adalah $\mathrm{ZnCl}_{2}$ karena mempunyai sifat tidak berwarna, tidak berbau, tidak mengendap, dan tidak menimbulkan perubahan rasa. Pada penelitian sebelumnya fortifikasi besi dengan perbandingan 1:1 di dalam produk susu tidak memiliki efek merugikan pada absorbsi $\mathrm{Zn} .{ }^{15}$

Susu merupakan media fortifikasi besi yang baik karena mempunyai nilai bioavailabilitas dan nilai gizi tinggi serta dikonsumsi secara luas. Susu kambing memiliki kandungan protein 3,49\% dan lemak 5,23\% yang lebih tinggi dibandingkan dengan susu sapi sehingga mempengaruhi kualitas asam serta nilai $\mathrm{pH}$ pada yoghurt. ${ }^{4}$ Susu kambing mengandung asam lemak volatil (kaproat, kaprilat, dan kaprat) yang lebih tinggi dibanding susu sapi yang menyebabkan susu kambing mempunyai rasa dan aroma yang kurang sedap dibanding produk susu lain. ${ }^{5}$ Untuk meningkatkan organoleptik, susu kambing dapat diolah menjadi yoghurt dengan menggunakan Lactobacilus bulgaricus dan Streptococcus thermophilus yang menimbulkan rasa asam yang spesifik serta meningkatkan nilai cerna pada makanan. Yoghurt yang dihasilkan mengandung asam formiat yang akan mengurangi aroma tidak sedap pada susu kambing. Untuk meningkatkan ketahanan hidup probiotik diperlukan penambahan prebiotik. Inulin merupakan salah satu jenis prebiotik yang sering digunakan dalam fermentasi produk susu. Inulin memiliki sifat larut, mudah difermentasi, dan bersifat protektif terhadap probiotik sehingga dapat meningkatkan ketahanan hidup dan aktivitas probiotik selama masa penyimpanan. ${ }^{7}$ Penambahan inulin memodulasi pertumbuhan bakteri asam laktat sehingga mempengaruhi karakteristik sensoris dan fisik produk. ${ }^{8-11}$ Karakteristik rasa manis pada inulin diharapkan dapat meningkatkan kualitas rasa pada produk yang dihasilkan. ${ }^{12}$

Ion logam yang terdapat pada garam $\mathrm{FeSO}_{4}$ dan $\mathrm{ZnCl}_{2}$ dapat mengurangi jumlah bakteri asam laktat pada yoghurt karena ion logam dapat merusak permeabilitas pada membran sel bakteri yang menyebabkan terhambatnya pertumbuhan bakteri. Menurunnya total bakteri asam laktat ini berpengaruh terhadap jumlah asam laktat yang dihasilkan sehingga $\mathrm{pH}$ yoghurt meningkat. Pada penelitian sebelumnya fortifikasi $\mathrm{FeSO}_{4} 40-100$ ppm pada yoghurt susu sapi berpengaruh terhadap nilai organoleptik menimbulkan rasa pahit seperti logam.
Fortifikasi mineral besi dan zinc pada yoghurt susu kambing sinbiotik dapat mengubah bakteri asam laktat, $\mathrm{pH}$, aroma, warna, tekstur, rasa sehingga perlu dilakukan penelitian untuk mengetahui pengaruh fortifikasi garam besi dan zinc terhadap total bakteri asam laktat, $\mathrm{pH}$ dan organoleptik yoghurt sinbiotik

\section{METODE}

Penelitian termasuk dalam bidang food production dan dilakukan mulai bulan April sampai Juni di Laboratorium Ilmu Gizi dan Teknologi Pangan Universitas Muhammadiyah Semarang serta di Program Studi Ilmu Gizi Universitas Diponegoro Semarang.

Penelitian ini merupakan penelitian eksperimental dengan rancangan acak lengkap satu faktor, yaitu jenis fortifikasi $\mathrm{FeSO}_{4}$ dan $\mathrm{ZnCl}_{2}$ pada yoghurt susu kambing sinbiotik. Terdapat 3 taraf perlakuan formulasi perlakuan yoghurt sinbiotik $(\mathrm{t}=3)$, yaitu $\left(\mathrm{t}_{0}\right)$ kontrol (tanpa fortifikasi), $\left(\mathrm{t}_{1}\right)$ fortifikasi $\mathrm{FeSO}_{4}$, ( $\left.\mathrm{t}_{2}\right)$ fortifikasi $\mathrm{FeSO}_{4}+\mathrm{ZnCl}_{2}$. Tiap kelompok perlakuan pada penelitian ini dilakukan 3 kali ulangan sehingga diperoleh 9 satuan percobaan dan pengujian dilakukan secara duplo.

Susu kambing yang digunakan adalah susu kambing cair peranakan Ettawa yang didapatkan dari peternakan kambing di Salatiga. Inokulum Lactobacillus bulgaricus dan Streptococcus thermophilus yang didapat dari Laboratorium Bioteknologi Fakultas Teknologi Pertanian Universitas Gadjah Mada. Mangga yang digunakan adalah mangga Gedong didapatkan dari Semarang dengan spesifikasi tidak banyak luka pada kulit, mencapai tingkat kematangan yang tepat dengan adanya aroma harum dari pangkal tangkai. Mangga diekstrak di Laboratorium Teknologi Pangan Fakultas Peternakan Universitas Diponegoro. Inulin didapatkan dari Laboratorium Ilmu Gizi Universitas Diponegoro.

Pada penelitian utama dilakukan pembuatan yoghurt sinbiotik menggunakan kultur, inulin, ekstrak mangga dan $\mathrm{FeSO}_{4}$ dan $\mathrm{ZnCl}_{2}$. Kultur dengan media agar tegak MRS Lactobacillus bulgaricus dan Streptococcus thermophilus dibiakkan dengan menggunakan susu skim sebanyak 25 gram, dilarutkan menggunakan $100 \mathrm{ml}$ air kemudian diinkubasi selama 11 jam dengan suhu $43^{\circ} \mathrm{C}$. Ekstrak mangga dibuat dengan cara dikupas, dicuci bersih kemudian dihaluskan dan disentrifuge dengan kecepatan $6000 \mathrm{rpm}$ selama 15 menit lalu disterilisasi menggunakan Lactoperoxide system. Susu kambing dipasteurisasi pada suhu $90^{\circ} \mathrm{C}$ 
selama 5 menit kemudian didinginkan, ditambahkan $5 \%$ inulin dan $5 \%$ gula pasir serta 55 ppm $\mathrm{FeSO}_{4}$ dan 15,6 ppm $\mathrm{ZnCl}_{2}$ sesuai dengan perlakuan. Susu kambing dihomogenisasi, ditambahkan ekstrak mangga $1 \%$ dan starter Lactobacillus bulgaricus serta Streptococcus thermophilus sebanyak 3\% kemudian diinkubasi selama 8 jam pada suhu $43^{\circ} \mathrm{C}$.

Tingkat keasaman yoghurt sinbiotik diukur menggunakan $\mathrm{pH}$ meter. Pengujian total bakteri asam laktat menggunakan metode Total Plate Count (TPC) pada media Man Rogosa and Sharpe (MRS). Uji hedonik dengan panelis agak terlatih sebanyak 25 orang dari Mahasiswa Ilmu Gizi Fakultas kedokteran Universitas Diponegoro dengan kategori tingkat kesukaan (1) sangat tidak suka, (2) tidak suka, (3) netral, (4) suka dan (5) sangat suka.

Pengolahan data menggunakan SPSS 16 for Windows. Pengaruh $\mathrm{FeSO}_{4}$ dan $\mathrm{ZnCl}_{2}$ terhadap $\mathrm{pH}$ yoghurt sinbiotik diuji menggunakan uji Kruskal Wallis dan total BAL diuji dengan menggunakan One Way Anova dilanjutkan dengan uji post hoc LSD.Organoleptik diuji menggunakan Friedman, dilanjutkan dengan uji Wilcoxon.

\section{HASIL}

\section{Nilai pH dan Total BAL Pada Yoghurt Sinbiotik}

Hasil analisis $\mathrm{pH}$ dan total bakteri asam laktat dapat dilihat pada Lampiran 1 dan secara singkat dapat dilihat pada Tabel 1.

Tabel 1. Nilai pH dan total BAL yoghurt susu kambing sinbiotik dengan fortifikasi ferrous sulfat dengan zinc klorida

\begin{tabular}{llc}
\hline \multicolumn{1}{c}{ Perlakuan } & pH & Total BAL (10 $\mathbf{c f f u}^{\mathbf{c}}$ \\
\hline Yoghurt kontrol & $4.65 \pm 0.04$ & $25.93 \pm 6.55^{\mathrm{a}}$ \\
Yoghurt dengan $\mathrm{FeSO}_{4}$ & $4.73 \pm 0.06$ & $15.63 \pm 0.76^{\mathrm{b}}$ \\
${\text { Yoghurt } \mathrm{FeSO}_{4}+\mathrm{ZnCl}_{2}}$ & $4.75 \pm 0.11$ & $9.55 \pm 1.55^{\mathrm{c}}$ \\
\hline & $\mathrm{P}=0.098$ & $\mathrm{P}=0.000$ \\
\hline
\end{tabular}

Berdasarkan hasil analisis data, fortifikasi $\mathrm{FeSO}_{4}$ dan $\mathrm{ZnCl}_{2}$ pada yoghurt sinbiotik meningkatkan nilai $\mathrm{pH}(\mathrm{p}=0,098)$. Secara statistik, $\mathrm{pH}$ yoghurt sinbiotik dengan $\mathrm{FeSO}_{4}$ dan $\mathrm{FeSO}_{4}+$ $\mathrm{ZnCl}_{2}$ tidak berbeda secara nyata dengan yoghurt sinbiotik kelompok kontrol.

Fortifikasi $\mathrm{FeSO}_{4}$ dan $\mathrm{FeSO}_{4}+\mathrm{ZnCl}_{2}$ $(\mathrm{p}=0.000)$ secara signifikan dapat menurunkan total bakteri asam laktat. Yoghurt sinbiotik dengan fortifikasi $\mathrm{FeSO}_{4}+\mathrm{ZnCl}_{2}$ mempunyai BAL yang paling sedikit dibandingkan dengan perlakuan lain $\left(9.55 \times 10^{7} \mathrm{cfu}\right)$.

\section{Organoleptik Yoghurt Sinbiotik}

Hasil analisis organoleptik warna, aroma, tekstur dan rasa yoghurt susu kambing disajikan pada Tabel 2.

Tabel 2. Analisis organoleptik warna, aroma, tekstur dan rasa yoghurt susu kambing

\begin{tabular}{|c|c|c|c|c|c|c|c|c|}
\hline \multirow{2}{*}{ Perlakuan } & \multicolumn{2}{|l|}{ Warna } & \multicolumn{2}{|l|}{ Aroma } & \multicolumn{2}{|l|}{ Tekstur } & \multicolumn{2}{|l|}{ Rasa } \\
\hline & Rerata & Ket & Rerata & Ket & Rerata & Ket & Rerata & Ket \\
\hline Yoghurt Kontrol & $3,48 \pm 0,77$ & Netral & $3,48 \pm 0,82^{\mathrm{a}}$ & Netral & $3,84 \pm 0,62^{\mathrm{a}}$ & Suka & $3,32 \pm 1,06$ & Netral \\
\hline Yoghurt $\mathrm{FeSO}_{4}$ & $3,28 \pm 0,61$ & Netral & $2,92 \pm 0,95^{\mathrm{b}}$ & Netral & $3,28 \pm 1,10^{\mathrm{b}}$ & Netral & $2,84 \pm 1,31$ & Netral \\
\hline \multirow[t]{2}{*}{ Yoghurt $\mathrm{FeSO}_{4}+\mathrm{ZnCl}_{2}$} & $3,52 \pm 0,51$ & Suka & $2,68 \pm 1,18^{\mathrm{b}}$ & Netral & $3,28 \pm 0,79^{b}$ & Netral & $2,56 \pm 1,08$ & Netral \\
\hline & $\mathrm{p}=0,200$ & & $\mathrm{p}=0,022$ & & $\mathrm{p}=0,037$ & & $\mathrm{P}=0.205$ & \\
\hline
\end{tabular}

Hasil analisis data menunjukkan, fortifikasi $\mathrm{FeSO}_{4}$ dan $\mathrm{FeSO}_{4}+\mathrm{ZnCl}_{2}$ tidak berpengaruh secara signifikan terhadap warna $(\mathrm{p}=0.200)$. Warna yoghurt sinbiotik dengan fortifikasi $\mathrm{FeSO}_{4} \quad+\mathrm{ZnCl}_{2}$ lebih disukai dibandingkan yoghurt yang hanya difortifikasi $\mathrm{FeSO}_{4}$ dan yoghurt kontrol.

Aroma yoghurt dengan fortifikasi $\mathrm{FeSO}_{4}$ maupun yoghurt dengan fortifikasi $\mathrm{FeSO}_{4}+\mathrm{ZnCl}_{2}$ dinilai lebih rendah dibandingkan dengan yoghurt kontrol meskipun semua perlakuan masuk dalam katagori netral $(\mathrm{p}=0.022)$. Demikian pada tekstur, yoghurt dengan fortifikasi $\mathrm{FeSO}_{4}$ dan yoghurt dengan fortifikasi $\mathrm{FeSO}_{4}+\mathrm{ZnCl}_{2}$ mempunyai tekstur yang kurang disukai dibandingkan dengan kelompok kontrol meskipun masih dalam kategori normal.

Yoghurt sinbiotik dengan atau tanpa fortifikasi $\mathrm{FeSO}_{4}$ dan $\mathrm{ZnCl}_{2}$ mempunyai tingkat kesukaan rasa yang sama yaitu netral. Fortifikasi yoghurt sinbiotik tidak berpengaruh secara signifikan terhadap tingkat penerimaan dalam parameter rasa $(\mathrm{p}=0,205)$.

\section{PEMBAHASAN \\ pH}

Yoghurt fortifikasi $\mathrm{FeSO}_{4}$ dan $\mathrm{FeSO}_{4}+$ $\mathrm{ZnCl}_{2}$ mempunyai $\mathrm{pH}$ yang lebih tinggi dibandingkan dengan kelompok kontrol $(4,6)$ yaitu 4,73 dan 4.75. Standart Nasional Indonesia 
menetapkan $\mathrm{pH}$ optimum yoghurt yaitu $4.6 .{ }^{16}$ Dengan demikian yoghurt yang difortifikasi $\mathrm{FeSO}_{4}$ dan $\mathrm{FeSO}_{4}+\mathrm{ZnCl}_{2}$ tidak memenuhi syarat SNI. Hal ini disebabkan terhambatnya pertumbuhan bakteri asam laktat akibat adanya ion logam yang bersifat toksik bagi bakteri. Ion $\mathrm{Fe}$ merusak permeabilitas sel bakteri yang menyebabkan jumlah bakteri semakin menurun sehingga asam yang dihasilkan oleh bakteri asam laktat juga semakin sedikit. Selain Fe, ion Zn juga merusak permeabilitas sel bakteri sehingga dengan adanya penambahan dua jenis mineral pada fortifikasi $\mathrm{FeSO}_{4}+\mathrm{ZnCl}_{2}$ menyebabkan berkurangnya jumlah asam yang dihasilkan oleh bakteri asam laktat berdampak pada meningkatnya nilai $\mathrm{pH}$ pada yoghurt dengan fortifikasi Fe dan $\mathrm{Zn}$.

\section{Total Bakteri Asam Laktat}

Fortifikasi $\mathrm{FeSO}_{4}$ dan $\mathrm{FeSO}_{4}+\mathrm{ZnCl}_{2}$ secara signifikan menurunkan total bakteri asam laktat yaitu $15,63 \times 10^{7}$ dan $9,55 \times 10^{7}$. Yoghurt sinbiotik dengan fortifikasi $\mathrm{FeSO}_{4}+\mathrm{ZnCl}_{2}$ mempunyai $\mathrm{BAL}$ yang lebih sedikit dibandingkan dengan perlakuan lain namun jumlah ini masih dalam standar SNI sebesar $1 \times 10^{7} \mathrm{cfu} / \mathrm{ml}$.

Total bakteri asam laktat dapat dipengaruhi beberapa faktor diantaranya media tumbuh, lama fermentasi, lama inkubasi, suhu penyimpanan, kandungan nutrisi substrat, $\mathrm{pH}$ serta bahan tambahan yang digunakan di dalam pembuatan yoghurt. ${ }^{17}$ Penambahan $\mathrm{FeSO}_{4}$ menjadi toksik bagi bakteri asam laktat sehingga dapat menurunkan jumlah bakteri asam laktat. ${ }^{18}$

Penambahan $\mathrm{FeSO}_{4}$ sebanyak $55 \mathrm{mg} / \mathrm{l}$ susu menyebabkan penurunan bakteri asam laktat yang cukup signifikan. Ion $\mathrm{Fe}$ pada $\mathrm{FeSO}_{4}$ merusak permeabilitas membran sel bakteri sehingga pertumbuhan bakteri terhambat. Hal ini juga terjadi pada yoghurt dengan fotifikasi $\mathrm{FeSO}_{4}+\mathrm{ZnCl}_{2}$, ion $\mathrm{Fe}$ dan $\mathrm{Zn}$ semakin mempengaruhi kerusakan membran sel pada bakteri. Adanya ion - ion logam akan merusak permeabilitas membran. Total bakteri asam laktat semakin menurun jumlahnya ketika diberikan fortifikasi dengan dua mineral yaitu Fe dan Zn.

\section{Organoleptik}

Warna

Fortifikasi $\mathrm{FeSO}_{4}$ dan $\mathrm{FeSO}_{4}+\mathrm{ZnCl}_{2}$ tidak berpengaruh secara signifikan terhadap warna $(\mathrm{p}=0.200)$. Warna yoghurt sinbiotik dengan fortifikasi $\mathrm{FeSO}_{4}+\mathrm{ZnCl}_{2}$ lebih disukai dibandingkan yoghurt yang hanya difortifikasi $\mathrm{FeSO}_{4}$ dan yoghurt kontrol. Pada yoghurt dengan fortifikasi besi semakin tinggi kadar besi yang ditambahkan makan penerimaannya akan semakin menurun akibat adanya interaksi antara susu dengan besi yang menyebabkan perubahan warna. Pada penelitian fortifikasi 55 ppm $\mathrm{FeSO}_{4}$ pada kecap tidak menyebabkan perubahan warna. Ekstrak mangga $1 \%$ yang ditambahkan tidak mengubah warna yoghurt sinbiotik, begitu juga pada kelompok perlakuan dimana $\mathrm{FeSO}+\mathrm{ZnCl}_{2}$ dimana $\mathrm{ZnCl}_{2}$ merupakan jenis zinc yang tidak menyebabkan perubahan warna. Pada penelitian sebelumnya, penambahan $\mathrm{Zn}$ pada keju tidak ditemukan perubahan warna. ${ }^{14}$ Fortifikasi besi yang ditambahkan sebanyak 55 ppm sesuai dengan resiko toksisitas yaitu $11 \mathrm{mg}$ dengan RDA $25 \%$. $^{9}$ Hasil uji warna menunjukkan bahwa tidak terdapat perbedaan warna antara kelompok kontrol dan perlakuan.

\section{Aroma}

Aroma yoghurt dengan fortifikasi $\mathrm{FeSO}_{4}$ maupun yoghurt dengan fortifikasi $\mathrm{FeSO}_{4}+$ $\mathrm{ZnCl}_{2}$ memiliki aroma yang lebih rendah dibandingkan dengan yoghurt kontrol meskipun dalam katagori netral $(\mathrm{p}=0.022)$. Fortifikasi $\mathrm{Fe}$ dapat menyebabkan oksidasi flavour dan rasa besi pada produk yang ditambahkan. Pada penelitian lain, fortifikasi besi pada keju dengan penambahan besi $40 \mathrm{mg}$ memiliki nilai organoleptik yang paling disukai, namun semakin tinggi kadar mineral yang ditambahkan dapat menimbulkan bau karat. ${ }^{23}$ Fortifikasi $\mathrm{Zn}$ tidak menimbulkan perubahan aroma sesuai dengan jenis fortifikan. Penerimaan aroma yoghurt dengan fortifikasi besi dan $\mathrm{Zn}$ dipengaruhi adanya reaksi oksidasi yang menyebabkan bau karat meskipun tidak tercium secara nyata.

Seluruh perlakuan memiliki aroma khas susu kambing yang disebabkan oleh tingginya kadar lemak volatil seperti kaproat, kaprat dan kaprilat. Aroma ini telah diminimalisir dengan proses fermentasi susu kambing dimana pada suhu 40'C bakteri asam laktat akan bersama sama menghasilkan asam, lactobacillus bulgarcus menghasilkan glisin dan histidin yang akan merangsang Streptococcus thermophilus untuk menghasilkan aroma asam. ${ }^{20}$

\section{Tekstur}

Hasil uji tingkat kesukaan pada yoghurt susu kambing di dapatkan tingkat kesukaan yoghurt kontrol dalam kategori suka sedangkan yoghurt dengan fortifikasi $\mathrm{FeSO}_{4}$ dan yoghurt dengan fortifikasi $\mathrm{FeSO}_{4}+\mathrm{ZnCl}_{2}$ dikategorikan netral. Tekstur yoghurt cair semi padat sesuai dengan standart SNI mutu yoghurt. ${ }^{5}$ Tekstur yoghurt dapat diterima panelis yang ditunjukkan dengan nilai tertinggi pada yoghurt tanpa fortifikasi yaitu 3.84 dan nilai pada yoghurt sinbiotik fortifikasi $\mathrm{FeSO}_{4}$ dan yoghurt sinbiotik 
fortifikasi $\mathrm{FeSO}_{4}+\mathrm{ZnCl}_{2}$ sama yaitu 3.28. Penilaian tekstur yang lebih rendah pada fortifikasi yoghurt dengan penambahan $\mathrm{Fe}$ dipengaruhi oleh total bakteri asam laktat yang rendah yang kemudian mempengaruhi kekentalah yoghurt. Pada yoghurt dengan fortifikasi $\mathrm{Fe}$ dan $\mathrm{Zn}$ memiliki teksur yang lebih rendah akibat jumlah bakteri asam laktat yang terkandung juga rendah sehingga mempengaruhi pembentukan gel pada yoghurt. ${ }^{22}$ Tekstur yoghurt dapat dipengaruhi oleh banyak faktor seperti bahan utama penyusun yoghurt (jenis susu) dan lama penyimpanan. Pada penelitian sebelumnya fortifikasi $\mathrm{Zn}$ dan $\mathrm{Fe}$ pada keju menunjukkan tingkat kekerasan produk yang lebih tinggi dibandingkan dengan kelompok kontrol. ${ }^{14}$

Rasa

Yoghurt sinbiotik dengan atau tanpa fortifikasi $\mathrm{FeSO}_{4}$ dan $\mathrm{ZnCl}_{2}$ mempunyai tingkat kesukaan rasa yang sama yaitu netral. Fortifikasi yoghurt sinbiotik tidak berpengaruh secara signifikan terhadap tingkat penerimaan dalam parameter rasa $(\mathrm{p}=0,205)$.

Fortifikasi $\mathrm{FeSO}_{4}$ dan $\mathrm{ZnCl}_{2}$ di dalam penelitian ini menurunkan nilai organoleptik dalam segi rasa jika dibandingkan dengan kelompok kontrol karena adanya penambahan $\mathrm{FeSO}_{4}$ dan $\mathrm{ZnCl}_{2}$ menimbulkan reaksi oksidasi yang menyebabkan perubahan rasa pada yoghurt. Semakin tinggi penambahan $\mathrm{FeSO}_{4}$ dan $\mathrm{ZnCl}_{2}$ maka akan semakin menyebabkan perubahan rasa pahit seperti logam. Pada penelitian lain, penambahan 40ppm $\mathrm{FeSO}_{4}$ pada produk keju memiliki tingkat organoleptik yang paling diterima oleh panelis, sedangkan semakin tinggi penambahan $\mathrm{FeSO}_{4}$ pada produk keju dapat menimbukan rasa berkarat. ${ }^{14}$

\section{SIMPULAN}

1. Fortifikasi $\mathrm{FeSO}_{4}$ dan $\mathrm{FeSO}_{4}+\mathrm{ZnCl}_{2}$ menurunkan total bakteri asam laktat secara nyata dan meningkatkan nilai $\mathrm{pH}$.

2. Forttifikasi $\mathrm{FeSO}_{4}$ dan $\mathrm{FeSO}_{4}+\mathrm{ZnCl}_{2}$ menurunkan nilai aroma, tekstur (secara nyata) warna, dan rasa ( secara tidak nyata).

\section{SARAN}

Perlu dilakukan penelitian lebih lanjut untuk meningkatkan organoleptik diantaranya aroma, warna, rasa dan tekstur yoghurt sinbiotik

\section{DAFTAR PUSTAKA}

1. Departemen Kesehatan Republik Indonesia. Laporan Hasil Riset Kesehatan Dasar (RISKESDAS) Indonesia. Jakarta.2013
2. Boycheva S., Dimitrov T., Naydenova N., Mihaylova G. Quality characteristics of yogurt from goat's milk, supplemented with fruit juice. Czech J. Food Sci.,2011. 29: 24-30

3. Allen L., de Benoist B., Dary O., Hurrell R. Guidelines on food fortification with micronutrients. World Health Organization and Food and Agriculture Organization of the United Nations. Geneva.2008

4. Vaclavik V. A., Christian E. W. Essentials of Food Science. Springer. New York.2008. ISBN 978-0387-69939-4.

5. El-Kholy A.M., Osman M., Gouda A., Ghareeb Wafaa A. Fortification of Yoghurt with Iron. World Journal of Dairy \& Food Sciences 6.2011 (2): 159-65.

6. Hidayat I.R., Kusrahayu, Mulyani S. Total Bakteri Asam Laktat, Nilai pH dan Sifat Organoleptik Drink Yoghurt dari Susu Sapi yang diperkaya dengan Ekstrak Buah Mangga. Animal agriculture journal.2013.Vol. 2. 160-67

7. Hoppert K., Zahn S., Janecke L., Mai R., Hoffmann S., Rohm H. 2013. Consumer acceptance of regular and reduced-sugar yogurt enriched with different types of dietary fiber. International Diary Journal 28 (2013) 1-7.

8. Carabin I.G., Flamm W.G. Evaluation of safety of inulin and oligofructose as dietary fiber. Regulatory tosicology and pharmacology,1999; 30: $268-82$

9. Kristo E., Biliaderis C.G., Tzanetakis N. Modeling of the acidification process and rheological properties of milk fermented with a yogurt starter culture using response surface methodology. Food Chemistry 83.2003; (3), 437-46

10. Oliveira R.P.S., Perego P., Converti A., Oliveira M.N. The effect of inulin as a prebiotic on the production of probiotic fibre-enriched fermented milk. International Journal of Diary Technology 62, 2009; (2), 195-203.

11. Ruas-Madiedo P., Hugenholtz J., Zoon P. An overview of the functionality of exopolysaccharides produced by lactic acid bacteria. International Diary Journal.2012;12 (2), 163-71

12. Jackson L.S., Lee K. Microencapsulated iron food fortification. J. Food Sci. 1991;56: 1047-050.

13. Darlan Azhar. Fortifikasi dan ketersediaan zat besi pada bahan pangan berbasis kedelai dengan menggunakan fortifikasi $\mathrm{FeSO}_{4} \cdot 7 \mathrm{H}_{2} \mathrm{O}$ campuran $\mathrm{FeSO}_{4} 7 \mathrm{H}_{2} \mathrm{O}+\mathrm{Na}_{2} \mathrm{H}_{2}$ EDTA. $2 \mathrm{H}_{2} \mathrm{O}$ dan NaFeEDTA. Departemen Kimia Fakultas Matematika dan Ilmu Pengetahuan Alam Universitas Indonesia. Depok.2012

14. Kahraman O. Effect of milk fortification with zinc on lactic acid bacteria activity and cheese quality [Thesis]. Polytechnic University of Marche. Ancona. Italy.2011

15. Bakta I made, SuegaKetut, DharmayudaTjokordaGde. Anemia 
DefisiensiBesidalamBukuAjarllmuPenyakitDalam. Editor: SudoyoAru W, SetiyohadiBambang, AlwiIdrus, K. Marcellus Simadibrata, SetiatiSiti. Jilid II edisi IV DepartemenIlmuPenyakitDalamFakultasKedoktera nUniversitas Indonesia. 2006

16. Lee WJ danLucey JA. Formation and physical properties of yogurt. Asian-Aust. J. Anim. Sci. 2010; 23(9): 1127-1136.

17. Nadra MCM. Nitrogen metabolism in lactic acid bacteria from fruits: a review. Communicating Curent Research and Educational Topics and Trends in Applied Microbiology, 2007; 500-510.

18. Hui YH, editor. Handbook of food products manufacturing: health, meat, milk, poultry, seafood, and vegetables. New Jersey: John Wiley \& Sons, Inc.; 2007.

19. Helmi EM, Harini S, Lusiastuti. Peningkatan kualitas yoghurt dari susu kambing dengan penambahan bubuk susu skim dan pengaturan suhu pemeraman, 2009:185-192.

20. Djurdjević JD, Maćej O, dan Jovanović S. The influence of investigated factors on viscosity of stirred yogurt. Journal of Agricultural Sciences, 2002; 47(2): 219-231.

21. Amanah,Nur. Identifikasi dan karakterisasi substrat antimikroba dari bakteri asam laktat kandidat prebiotik yang diisolasi dari dadih dan yoghurt. Institut Pertanian Bogor.2011

22. El-Din A.M.G.,Hasan, El-Behairy S.A., Mohamed E.A.Impact of Zinc and Iron Salt fortification of Buffalo's milk on diary product. World Journal of Dairy \& Food Science,2012; 7(1):21-27

23. Hudawi N, Eka L, Rosyidi D. Pengaruh Penambahan Berbagai Konsentrasi Kultur Dan Lama Pemeraman Pada Suhu Ruang Terhadap pH, Viskositas dan Kadar Keasaman Dan Total Plate Count Set Yoghurt.Universitas Brawijaya Malang.2007 